\section{Miskunn mot redelighet}

I Tidsskriftet nr. 15/2012 drøfter Eivind Meland en konkret hendelse der en ph.d.-kandidat fikk avvist sin doktoravhandling på bakgrunn av plagiat i sammenstillingsdelen (1). Undertegnede møtte i fakultetsstyret på det tidspunktet avgjørelsen falt og har, som Meland, allerede en mening om saken. Som nylig uteksaminert ph.d.-kandidat ønsker jeg likevel å kommentere hans innlegg.

Det er mange utfordringer knyttet til det å avlegge en ph.d.-grad. Data skal samles og analyseres, artikler skrives, sendes inn og revideres, medforfatterskap fordeles. Tiden går fort. Når man har publisert et tilstrekkelig antall artikler, er det på tide å skrive selve avhandlingen, et sammendrag av bakgrunn og resultater, og sette sine funn inn i en sammenheng hvor resultatene diskuteres i lys av øvrige funn fra forskningsfeltet. Mange får knapt med tid i denne fasen. Rammene for sammenskrivingen har vært relativt frie, ofte preget av lokal tradisjon. Underveis må man foreta mange avveininger. Som Meland påpeker - skillet mellom redelighet og uredelighet kan være flytende. Men det er ikke alltid vanskelig å avgjøre når grensen er overskredet.

De færreste vil ha problemer med å forstå at det å få refusert sin doktoravhandling er ille og at det kan få karrieremessige konsekvenser. Kan det i tillegg tenkes at opplevelsen av krenkelse har sammenheng med følelsen av å være avslørt i forsøk på fusk? For de ph.d.-kandidatene som har brukt dager og uker på å sette sammen sin egen tekst, vil det kanskje oppleves som noe i retning av krenkende at en som har klippet og limt, får anledning til å revidere og forsvare sin avhandling? For å snu på spørsmålet: Er frykten for å påføre andre (profesjonell) krenkelse grunn god nok til å se gjennom fingrene med forsøk på juks?

Universitetet i Bergen har utarbeidet et reglement for ph.d.avhandlinger. Her heter det: «Avhandlingen skal være et selvstendig, vitenskapelig arbeid som oppfyller internasjonale standarder innen fagområdet.» Må det stå i dette reglementet at avskrift fra andres arbeider ikke er tillatt? Etter min mening vil behovet for eksplisitt å nedfelle denne type selvfølgeligheter undergrave ph.d.-gradens posisjon som den høyeste akademiske grad i Norge. Dersom ph.d.-kandidaten har et annet forhold til det å sitere kilder enn det som er vanlig innen vitenskapen ellers, er det forskningsmiljøets ansvar å sørge for at kandidaten endrer sin praksis.

Til slutt vil jeg komme med en oppfordring. Meland omtaler avgjørelsen som ble tatt vedrørende ph.d.-avhandlingen som et uttrykk for moralsk «schizofreni». Eugene Bleuler anvendte riktignok begrepene «Zerreißung» og «Spaltung» da han introduserte schizofrenibegrepet, som i seg selv betyr «splittet sinn». Men den vulgære bruken av schizofrenibegrepet som synonym for dikotomi eller ambivalens, stadig sett i dagspressen, hører ikke hjemme i en faglig debatt. Bland gjerne inn Jesus fra Nasaret, men hold schizofrene pasienter utenfor.

\section{Silje Skrede}

silje.skrede@med.uib.no

Silje Skrede (f. 1979) er lege og forsker ved Senter for medisinsk genetikk og molekylærmedisin, Haukeland universitetssykehus.

Oppgitte interessekonflikter: Forfatteren er vararepresentant for gruppe $\mathrm{B}$ (midlertidige vitenskapelig ansatte) i fakultetsstyret ved Det medisinskodontologiske fakultet ved Universitetet i Bergen og har deltatt i behandlingen av den konkrete saken debatten springer ut fra.

\footnotetext{
Litteratur

1. Meland E. Forskningsetikk, sannhet og kjærlighet. Tidsskr Nor Legeforen 2012; 132: $1731-2$.
}

Publisert som rask respons i nettutgaven 22.8. 2012

\section{E. Meland svarer:}

Silje Skrede spekulerer i om en påstått krenkelseserfaring hos en utvist ph.d.-kandidat egentlig er uttrykk for skamfølelse over å ha blitt avslørt i forsøk på fusk. Anklagen om bevisst å ha forsøkt å føre bedømmelseskomité og fakultet bak lyset var kjernen i Det medisinsk-odontologiske fakultets (MOFs) prosess mot kandidaten. Disse beskyldningene er nå kjent usaklige og udokumenterte av Universitetet i Bergens eget granskingsutvalg $(1,2)$. At et fakultetsstyremedlem nå finner det opportunt å gjenta disse beskyldningene i full offentlighet, representerer en dobbelt krenkelse.

Jeg har brukt begrepet «schizofreni» om fenomener i vår samtid der moralen frakobles kjærlighet og barmhjertighet. Jeg har også brukt begrepet for å beskrive hva som skjer med pedagogikken når den perverteres til kunnskapsproduksjon. Jeg har ikke karakterisert Det medisinsk-odontologiske fakultets saksbehandling og fakultetsstyrets vedtak med en diagnose hentet fra sykdomsklassifikasjoner. Vi har fullt dekkende begreper i det norske hverdagsspråket for å karakterisere dette: selvrettferdighet og dømmesyke.

\section{Eivind Meland}

eivind.meland@isf.uib.no

Eivind Meland (f. 1950) er spesialist i allmennmedisin, fastlege ved Olsvik legesenter og professor ved Institutt for samfunnsmedisinske fag. Universitetet i Bergen.

Forfatter har fylt ut ICMJE-skjemaet og oppgir følgende interessekonflikt: Han har, sammen med 30 andre ansatte ved Universitetet i Bergen, garantert for et beløp som skal bidra til å dekke ph.d.-kandidatens saksomkostninger dersom universitetet ikke betaler.

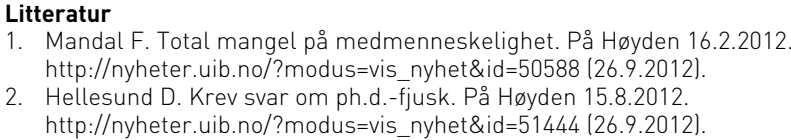

\section{Pasienten i sentrum}

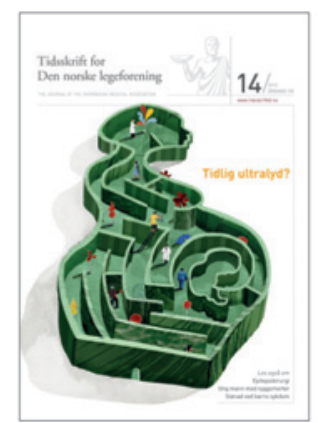

I Tidsskriftets gjesteskribentspalte hadde advokat Steinar Winther Christensen i nr. $14 / 2012$ et interessant innlegg om pasientskadeerstatning (1). Han har flere gode poenger, men vi mener likevel det er grunn til å presisere noen forhold. Winther Christensen skriver at det store flertall som melder sin skade får avslag og at av dem som klager til nemnda får ca. $10 \%$ medhold (1). Dette utsagnet kan være egnet til å forlede leseren til å tro at det kun er $10 \%$ av sakene som meldes til Norsk pasientskadeerstatning (NPE) som får medhold. Det er jo ikke tilfellet. Om lag en tredel av dem som fremmer et erstatningskrav får medhold, og bare i fjor utbetalte Norsk pasientskadeerstatning nesten 850 millioner kroner i erstatninger. Av de to tredelene som får avslag, påklager ca. $40 \%$ avslaget til Pasientskadenemnda. Rundt $10 \%$ av disse igjen får medhold i nemnda.

Winther Christensen skriver videre at «det er de sakkyndige leger som i praksis avgjør saken». Det er riktig at de sakkyndiges vurderinger er svært sentrale i utredningen av om det for eksempel foreligger behandlingssvikt. Avgjørelsene i sakene fattes imidlertid på juridisk grunnlag av saksbehandlere i Norsk pasientskadeerstatning. De sakkyndige kan og skal heller aldri være mer enn sentrale premissleverandører for våre avgjørelser.

Vi har også lyst til å kommentere Winther Christensens omtale av staten som pasientens motpart. Norsk pasientskadeerstatning 